\title{
Concern grows over 'trade' in Russian fossils
}

Munich. A scientifically important fossil stolen more than two years ago from the Museum of the Palaeontological Institute in Moscow has been returned, thanks to the efforts of a German museum curator who identified it and fought for its return.

But around 50 others are still missing. And, with thefts occurring at other institutes as well, there is evidence that some researchers, faced with declining salaries, may be involved in the illegal export of fossil specimens from scientific collections.

The Palaeontological Institute, whose museum became the main repository for the former Soviet Union's fossil treasures, is part of the Russian Academy of Sciences. Its world-renowned collection of fossils was started by Peter the Great in the eighteenth century and includes important specimens from the Permian and Triassic periods.

Following the fall of communism in 1990 and the country's ensuing economic collapse, the institute has been seeking alternative sources of finance to make up for the inadequacy of its state funding. At the same time, individual scientists have been under pressure to seek new sources of income.

The institute was given the role of protecting Russia's palaeontological heritage. A committee of its scientists, headed by the deputy director, Igor Novikov, is responsible for examining all requests for export licences for fossils. If it approves a request, this is formally endorsed by the ministry for the protection of the environment and natural resources.

There is growing evidence, however, that this system is being circumvented. In one theft in spring 1992, for example, fifteen 240-million-year-old Triassic skulls of labyrinthodonts, now-extinct amphibian ancestors, were stolen from the institute's amphibian collection.

Some of the stolen specimens are holotypes - reference samples for their species - and of great scientific value. Some specimens also have a high market value. The locked showcase containing the stolen fossils had not been broken. "Someone from the institute was certainly involved in the theft", says Michael Shishkin, head of the institute's amphibian division.

After Shishkin had reported the theft of the skulls in Lethaia Forum, a specialist journal, Rupert Wild, curator of the State Museum for Natural History in Stuttgart, Germany, became suspicious about a specimen bought by one of his volunteer technicians. Wild became suspicious that a Thoosuchus jacovlevi skull, bought for DM1,600 (US\$1,070)

from a German fossil dealer, Joachim Woerdemann, might be one of the stolen items.

The identification number on the skull, which had been partially scratched out but was still visible under special light, confirmed that it had once belonged to the institute's collection.

Nevertheless, the institute took little action to secure the return of the missing fossils. "Both Shishkin and myself were abroad for extended periods, and no-one else was interested", says Novikov.

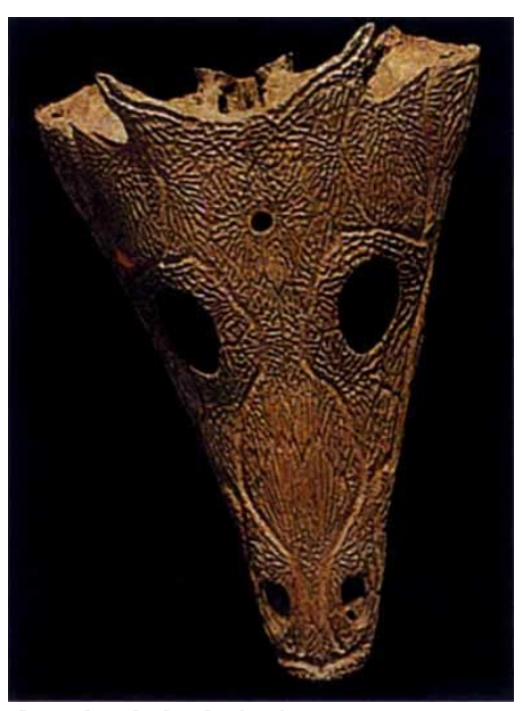

A stolen Labyrinthodont skull, now safely back in Moscow. the institute itself, remain alarmed at how scientifically important fossils, including vertebrate fossils for which no export licences have been recommended by the institute's committee, are still leaving the country.

But there is also concern about the implications of the commercial links that the institute has explored in its efforts to raise funds. In the spring of 1992, for example, the institute signed a cooperative agreement with a company called Kaminy Svetok ("stone flower"), to collect, identify and preserve fossils. The agreement specified that, in return, the institute would receive 20 per cent from all sales made through the company and that it would also receive 80 per cent of any sales of fossils from its own collection.

Some worry that involvement in a commercial project may put off potential collaborators. Others fear As a result, most of the effort to return the Thoosuchus skull came from Wild, who tried to have Woerdemann prosecuted.

Woerdemann, who has not returned telephone calls from Nature, has said that he has never bought any fossils from the institute. But he has admitted that the Thoosuchus skull obtained by Wild, which he claims to have bought from a private collector, may have originated from the museum.

No charges were brought against Woerdemann after the police said they did not have enough evidence to support a prosecution. But Woerdemann eventually agreed to buy back the skull, saying that he wanted to maintain good relations with the institute. It was collected in Germany last month by Novikov, who took it back to Moscow.

Scientists in the West, as well as many in

\section{\$1.8bn nuclear ignition facility for Livermore}

Washington. The US Department of Energy (DoE) has approved the design stage of the proposed \$1.8-billion National Ignition Facility (NIF) at the Lawrence Livermore laboratory, securing the future of the California as a nuclear weapons research complex.

The decision to proceed with the \$1.8 billion facility, which will use lasers to induce self-sustaining fusion, comes after months of pressure from the Department of Defense on Hazel O'Leary, the energy secretary, to proceed with the project in order to demonstrate her commitment to the nuclear weapons programme.

The DoE says that the NIF will be useful in astrophysics, in developing fusion power and in the safe maintenance of the nuclear stockpile. But critics say it will damage US efforts to halt the proliferation of nuclear weapons and that its chief function is to keep nuclear physicists in work pending any resumption of nuclear weapons development.
C. $M$. this arrangement represents a potential conflict of interest that could seriously undermine scientific research by tempting the institute to sell off important items in its scientific collections.

Even greater concern has been generated by evidence that some members of the institute may have set up a purely commercial operation, known as the Applied Palaeontological Institute (API), as a vehicle for the sale of fossils. Export papers for a specimen of a Pareiasaur, an ancestor of the turtle, on sale for $£ 40,000$ (US\$65,000) through a dealer in the United Kingdom, bear this name, and carry the same address as the academy's institute.

When contacted by a potential buyer, a staff member at the academy's institute initially acknowledged the API's existence. But other officials later denied all knowledge of the API. "I would very much like to know what the truth is", says Shishkin.

The Thoosuchus jacovlevi skull is the only specimen so far to have been located and returned. Others are believed to be in the United States, Japan, the United Kingdom and Germany. A joint British-Russian committee has been set up to locate and return the rest of the missing collection.

Meanwhile, Novikov says that in the past month the institute has forbidden its staff to take on commercial commitments and has cancelled its agreements with Kaminy Svetok.

Toni Feder \& Alison Abbott 